„Analecta Cracoviensia” 49 (2017), s. 111-128

DOI: http://dx.doi.org/10.15633/acr.2408

Lidia Macheta

Uniwersytet Jagielloński

\title{
Acedia a lype w pismach Ewagriusza z Pontu. Teo-antropologia ontologiczna
}

Niniejsze rozważania dotyczą relacji dwóch zjawisk Ewagriańskiej ${ }^{1}$ teo-antropologii: acedii ${ }^{2}$ i lype $^{3}$. Do podjęcia takiego zagadnienia skłaniają nas pewne rozbieżności w określaniu obydwu zjawisk, jakie pojawiają się w poświęconej

1 Na temat życia, nauki i pism Ewagriusza z Pontu (zm. 399), praktyka i teoretyka starożytnej ascezy, nazywanego „filozofem na pustyni”, „pierwszym mnichem teologiem”, zob. L. Nieścior, Wstęp, [w:] Ewagriusz z Pontu, Pisma ascetyczne, t. 1, tłum. K. Bielawski i in., Kraków 1998, s. 11-45; L. Nieścior, Wstęp, [w:] Ewagriusz z Pontu, Pisma ascetyczne, t. 2, tłum. M. Grzelak i in., Kraków 2005, s. 9-27. Fragmenty pism Ewagriusza przytaczamy z tych dwóch ich edycji; w artykule podajemy stosowane w literaturze przedmiotu skróty tytułów dzieł Ewagriusza oraz numery ich rozdziałów. Obszerna bibliografia na temat pism ascetycznych Ewagriusza zob. Evagrius of Pontus, The Greek Ascetic Corpus, ed. and trans. R. E. Sinkiewicz, New York-Oxford 2003, s. 334-345; L. Misiarczyk, Osiem „logismoi” w pismach Ewagriusza z Pontu, Kraków 2007, s. 387-408.

2 Używamy spolszczonego terminu łacińskiego: „acidia”, będącego zlatynizowaną wersją

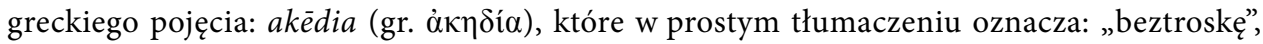
„niedbałość”; w przekładach pism Ewagriusza z Pontu na język polski termin „acedia” jest najczęściej tłumaczony na polskie „zniechęcenie”. O znaczeniu pojęcia acedii zob. L. Misiarczyk, Osiem „logismoi” w pismach Ewagriusza z Pontu, dz. cyt., s. 311; Encyklopedia chrześcijaństwa. Historia i współczesność, red. H. Witczyk, Kielce 200o, s. 31; L. Macheta, Unynije (Acedia), [w:] Idee w Rosji. Leksykon rosyjsko-polsko-angielski, t. 8, red. J. Dobieszewski, Łódź 2014, s. 446-463.

3 Używamy spolszczonego terminu greckiego: lýpē (gr. $\Lambda$ literaturze przedmiotu przyjęło się termin ten przekładać na słowo: „smutek”. Sądzimy bowiem, że tłumaczenie to nie oddaje w pełni znaczeń „lype”, jakie wkłada w nie Pontyk. W artykule posługujemy się terminem „lype” wyłącznie dla oznaczenia negatywnego zjawiska Ewagriańskiej teo-antropologii, czasami dodatkowo nazywanego w niej „światowym” (De mal. cogit. 14). Ewagriusz, w odniesieniu do tradycji Ojców Pustyni, wyróżnia dwa rodzaje lype: pożyteczne, „według Boga”, 
im literaturze przedmiotu. Wskażmy niektóre z tych rozbieżności. Jedne z nich dotyczą rozumienia cech swoistych acedii i lype. Część badaczy wiąże, na przykład, 'paraliż duchowy', 'przygnębienie' z acediąa , inni - z lype 5 . Kolejne omawiane rozbieżności dotyczą określenia więzi łączących acedię i lype. W rozumieniu niektórych znawców tematu lype jawi się jako cecha charakterystyczna acedii $^{6}$. W ujęciu innych różnica jakościowa między acedią a lype przestaje być wyraźna ${ }^{7}$ W koncepcji jeszcze innych uczonych acedia wprost utożsamia się z lype ${ }^{8}$. W świetle przywołanych ujęć relacji obu rozpatrywanych zjawisk jej charakter staje się problematyczny. Pewne rozwiązanie problemu tej relacji można uzyskać poprzez antropologiczne wyjaśnienie acedii i lype - poprzez ustalenie, jakie wymiary określają one w człowieku. Jeśli okaże się, że badane

oraz szkodliwe, grzeszne - „światowe” (De mal. cogit. 12), nawiązując tym samym do słów św. Pawła (2 Kor 7, 10 oraz 2 Kor 2).

4 Leszek Misiarczyk pisze: „Według Ewagriusza wyraża on [termin „acedia” - L. M.]: stan «duchowego zniechęcenia», «znużenia», «oschłości», «znudzenia», «tchórzostwa», «przygnębienia», «niezdolności do koncentracji na jednej czynności», «obrzydzenia», «zniechęcenia», «uprzykrzenia», "atonii duszy» czy wręcz "paraliżu duszy». [...] Acedia oznacza stan psychiczno-duchowy człowieka zbliżony do współczesnej depresji, który przejawia się często poczuciem pustki i bezsensu życia, w myślach lub nawet próbach samobójczych, niechęci do jakiegokolwiek działania, a także bezprzedmiotowym lęku czy wręcz paraliżu sił psychiczno-duchowych człowieka”, zob. L. Misiarczyk, Osiem „logismoi” w pismach Ewagriusza z Pontu, dz. cyt., s. 311.

5 Por. L. Nieścior, Smutek w nauce Ewagriusza z Pontu, „Życie Duchowe” 59 (2009), s. 24-34.

6 Por. słowa Misiarczyka: „Takie elementy jak zniechęcenie w codziennych życiowych zmaganiach, brak zaufania do Boga i doświadczenie smutku staną się dla późniejszych autorów chrześcijańskich, łącznie z Ewagriuszem, cechami charakterystycznymi acedii”, zob. L. Misiarczyk, Osiem „logismoi” w pismach Ewagriusza z Pontu, dz. cyt., s. 310.

7 Jean-Charles Nault ujmuje acedię i lype jako „siostry bliźniaczki”: „If Evagrius distinguishes acedia and sadness, he introduces them nonetheless as twin sisters", zob. J.-Ch. Nault, Acedia: Enemy of spiritual joy, „Communio” 31 (2004), s. 240-241. Zauważmy przy tym, że sam Ewagriusz posługuje się innym obrazem dla metaforycznego określenia relacji między acedią a lype: nazywa acedię „wspólniczką lype” (De vitiis 4); zaś lype - jej „towarzyszem” (De vitiis 3). Jean-Yves Leloup, w szerokim odniesieniu do Ewagriusza z Pontu, ujmuje acedię w sposób czyniący ją stopniem lype - nazywając ją wadą „smutniejszą od smutku”, zob. J.-Y. Leloup, Oczyszczanie logismoi u Ewagriusza Pontyjskiego, [w:] J.-Y. Leloup, Hezychazm. Zapomniana tradycja modlitewna, tłum. H. Sobieraj, Kraków 1996, s. 51.

8 Ryszard Przybylski pisze: „Akedia byłaby więc uczuciem, które św. Paweł nazywał smutkiem światowym, [...] przeciwieństwem smutku według Boga, [...] zmuszającym człowieka do zbawiennej pokuty $(2$ Kor 7, 10). Ten ziemski smutek dopadał eremitów bardzo często. [...] Pojawienie się akedii Ewagriusz z Pontu uważał za początek końca anachorezy. Wyjałowiony duch nie był już w stanie poszukiwać ani siebie, ani Boga. Pustelnik zaczynał żyć w zakłamaniu egzystencjalnym”, zob. R. Przybylski, Uraz do materii. Esej o nadmiarze możliwości, „Znak” (1993) nr 458 (7), s. 108. 
zjawiska wskazują na różne sfery w człowieku, wówczas, będzie można uznać za trafne tylko takie ujmowanie relacji acedii i lype, które nie zapoznaje istotnych, jakościowych, dzielących je różnic.

\section{Acedia a lype - Ewagriańska teo- -antropologia w ujęciu ontologicznym}

Antropologiczne wyjaśnienie acedii i lype będzie, w pierwszej kolejności, poszukiwane na gruncie teo-antropologii Ewagriusza, pośród jego bezpośrednich wypowiedzi. Dla potrzeb antropologicznego wyjaśnienia acedii i lype Pontyk czerpie pojęcia z platońskiej antropologii; jak pisze badacz: „Ewagriusz zgodnie z tradycją platońską rozróżnia w duszy część «rozum-

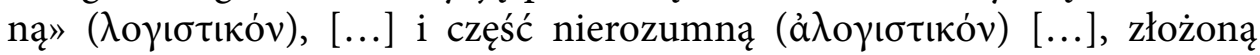

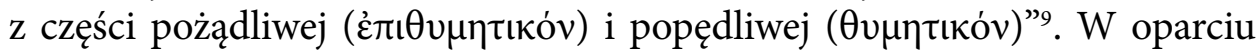
o kategorie tego podziału Ewagriusz różnicuje negatywne zjawiska swej

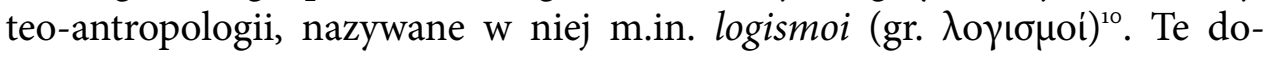
świadczane w sferze nierozumnej określa jako „przydarzające się nam jako zwierzętom” (Cap. cogn. 40), zaś logismoi doświadczane w sferze rozumnej jako „zdarzające się nam jako ludziom” (Cap. cogn. 40). Jak w pojęciach Ewagriańskiego rozróżnienia na logismoi irracjonalne i rozumne wygląda antropologiczne wyjaśnienie acedii i lype? Wyjaśnienie to odniesione przez Pontyka do acedii wykazuje pewną niejednoznaczność. W świetle jednych wypowiedzi Ewagriusza acedia jako jedyna z logismoi jest natury złożonej:

9 Zob. L. Nieścior, Wstęp, [w:] Ewagriusz z Pontu, Pisma ascetyczne, t. 1, dz. cyt., s. 25.

${ }^{10}$ W kontekście Ewagriańskiej nauki ascetycznej logismos (gr. $\lambda \mathrm{o} \gamma 1 \sigma \mu o ́ s$ ) jest zjawiskiem negatywnym Ewagriańskiej teo-antropologii (por. najczęściej stosowane polskie tłumaczenie greckiego terminu w zaznaczonym kontekście: 'zła myśl'). Pontyk wyróżnia osiem głównych logismoi; prócz acedii i lype wymienia: obżarstwo, nieczystość, chciwość, gniew, próżność, pychę. Acedię i lype, podobnie jak pozostałe logismoi, Ewagriusz wymiennie nazywa: demonem, pokusą, namiętnością oraz wadą czy usposobieniem duszy - nie utożsamiając tych różnych zjawisk, lecz chcąc, jak można sądzić, podkreślić, iż zachodzi między nimi ścisły związek. Z jego perspektywy każde z logismoi, w tym acedia i lype, daje się określić jako (kilkuelementowa) struktura zła teo-antropologicznie znaczącego. Na temat Ewagriańskich kategorii logismoi zob. L. Nieścior, Kategorie myśli w nauce ascetycznej Ewagriusza z Pontu, „Roczniki Humanistyczne” 44 (1996) z. 3,

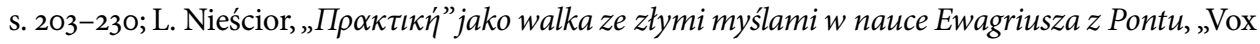

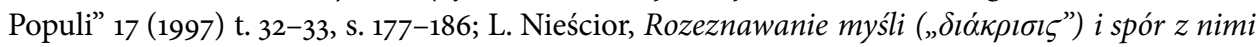

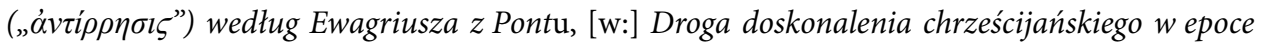
patrystycznej, red. F. Drączkowski, J. Pałucki, Lublin 1997, s. 31-56; L. Misiarczyk, Osiem „logismoi” w pismach Ewagriusza, dz. cyt., passim. 
„Te [logismoi - L. M.], które wywołane są przez zniechęcenie, mają mieszane pochodzenie i zdarzają się nam jako zwierzętom i ludziom równocześnie" (Cap. cogn. 40). W myśl innych zapisów Pontyka acedia określa w człowieku tylko sferę irracjonalną: „acedia to jednoczesne i długotrwałe pobudzenie popędliwości i pożądliwości” (Scholia in psalmos 118) ${ }^{11}$. Ewagriańskie wyjaśnienie antropologiczne odniesione do lype znamionuje pewna niewystarczalność. Wprawdzie zostaje ono przez Ewagriusza jednoznacznie zaliczone do logismoi rozumnych ${ }^{12}$, jednak nie otrzymuje ono od Pontyka takiego określenia, które w sferze antropologicznej pozwalałoby odróżnić je od pozostałych logismoi rozumnych.

Przywołane Ewagriańskie antropologiczne określenia acedii i lype przywodzą do dwóch ważnych dla nas konstatacji. Po pierwsze, określenia te nie dostarczają podstaw jednoznacznych (acedia) i wystarczających (lype) dla rozstrzygnięcia pytania o relację acedii i lype - dla wskazania sfer ich występowania w człowieku. Po drugie, w myśl tych określeń na płaszczyźnie antropologicznej acedia wyróżnia się spośród wszystkich logismoi i jako taka nie daje się utożsamiać $z$ lype. Rozpatrywane wespół konstatacje te skłaniają, by rozważyć tezę o zachodzeniu istotnych różnic między acedią i lype. Celem poniższych analiz będzie uzasadnienie antropologiczne tej tezy na drodze pokazania, że oba zjawiska wskazują w człowieku na różne wymiary.

\section{Acedia a lype - aksjologia egzystencjalna w ujęciu ontologicznym}

Zamierzonych analiz nie możemy, z powodów wyżej określonych, oprzeć na pojęciach teo-antropologii Pontyka. Analizy te obejmą wymiar egzystencjalny Ewagriańskiego doświadczenia acedii i lype. Treści tego doświadczenia będą opisywane i wyjaśniane w ogólnych pojęciach aksjologii egzystencjalnej ${ }^{13}$. $\mathrm{Na}$ jej gruncie byt człowieka, rozumianego jako egzystencja, jest ściśle związany z wartościami. Urzeczywistniając je, egzystencja staje się wartościowa ${ }^{14}$.

${ }^{11}$ Por. słowa Ewagriusza: „Pokusa ta [acedia - L. M.] [...] jest złożona z kilku myśli, ponieważ powstaje z gniewu i pożądliwości” (Ep. 27,6).

${ }_{12}$ Zob. słowa Ewagriusza: „Te zaś [logismoi - L. M], które zdarzają się nam się jako ludziom, pojawiają się jako skutek przygnębienia [lype - L. M.], próżnej chwały i pychy” (Cap. cogn. 40).

${ }_{13}$ Głównie w odniesieniu do fenomenologii aksjologicznej Maxa Schelera.

${ }^{14}$ Władysław Stróżewski, przyjmując egzystencjalną interpretację wartości, o zależności łączącej ją z egzystencją napisze: „Wartość dzieli istnienie ze swym podmiotem, nadaje mu jednak swoistą godność, wiążącą się bezpośrednio z jego istnieniem. Przedmiot nie tyle posiada wartość, 
Rozpatrywane z perspektywy aksjologii egzystencjalnej acedia i lype dadzą się ujmować jako nastawienie aksjologiczne. Szukać w egzystencji wymiaru określanego przez acedię i lype to zarazem szukać ich przedmiotowego korelatu - typu wartości, do których się odnoszą. Przyjmując tak określone podejście badawcze do problemu relacji acedii i lype, wychodzimy z szerszego przeświadczenia, że Ewagriański zapis doświadczenia monastycznego kryje w sobie uniwersalny sens antropologiczny ${ }^{15}$. I jako taki sens ten, w tym doświadczenia acedycznego i lypicznego, nie daje się sprowadzić wyłącznie do treści określonych, lokalnie i historycznie, przez swoje pochodzenie - przez środowisko anachoreckie czasów Ewagriusza z Pontu.

\section{Ewagriański mnich jako podmiot doświadczenia acedycznego i lypicznego}

W określonym powyżej nastawieniu badawczym wskazywany przez Ewagriusza podmiot doświadczenia monastycznego, w tym acedycznego i lypicznego, mnich-anachoreta ${ }^{16}$ jest rozumiany jako typ człowieka (resp. egzystencji). Kim jest w ten sposób ujmowany Ewagriański mnich? W sensie podstawowym jest on, mówiąc językiem Pontyka, typem człowiekiem duchowego ${ }^{17}$. Jego właściwym celem jest doskonalenie - poznawanie siebie, własnego „umysłu”18 (Ep. ad Mel. 16, 20), który w myśli Pontyka oznacza sferę właściwie ludzką w człowieku - jego człowieczeństwo. Kres tego doskonalenia - doskonałość duchowa (Pr. 68) - jest w pismach Ewagriusza określany w pojęciach samopoznania ${ }^{19}$,

ile staje się, a w końcu jest wartościowy”, zob. W. Stróżewski, Od wartości bytu do bytu wartości, [w:] Dziedzictwo aksjologii fenomenologicznej. Studia i szkice, red. P. Duchliński, Kraków 2011, s. 33.

15 Na temat znaczenia uniwersalnego tego zapisu zob. P. Kaznowski, Krótka historia metafizycznego znużenia, „Christianitas” 44 (2010), zwł. s. 50-53; L. Macheta, Aktualność Ewagriańskiej koncepcji ośmiu logismoi. Antropologia duchowości, [w:] Chrześcijaństwo a współczesne koncepcje człowieka, red. L. Suchanek, Kraków 2013.

${ }^{16} \mathrm{Na}$ temat Ewagriańskiej kategorii anachorezy zob. L. Nieścior, Anachoreza w pismach Ewagriusza $z$ Pontu, Kraków 1997.

${ }_{17}$ Por. słowa Ewagriusza: „Anachoretą jest ten, kto nabożnie i sprawiedliwie żyje w świecie duchowym” (Cap. Cogn. 14).

${ }^{18}$ Jedno z kluczowych pojęć Ewagriańskiej teo-antropologii. Na temat Ewagriańskiej antropologii zob. L. Misiarczyk, Antropologia mnicha z Pontu, [w:] L. Misiarczyk, Osiem „logismoi” w pismach Ewagriusza $z$ Pontu., dz. cyt., s. 95-115.

19 Por. słowa Ewagriusza: „Chcesz poznać Boga? Najpierw poznaj samego siebie” (Spirit. sent. 2) oraz „Początkiem zbawienia jest poznanie samego siebie” (Capit. paraen. 1). 


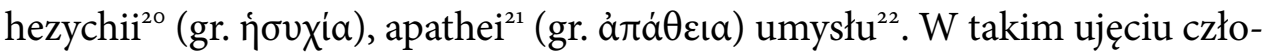
wieczeństwo Ewagriańskiego człowieka (resp. egzystencji) jawi się jako zadanie do osiągnięcia. Można go wobec tego rozpatrywać na płaszczyźnie antropologii ontologicznej. Bada ona człowieka od strony możliwości i powinności bycia sobą $^{23}$. Na gruncie onto-antropologii pełnia bycia sobą egzystencji aksjologicznej polega na urzeczywistnieniu naczelnych dla niej wartości pozytywnych $^{24}$. Pełnia bycia sobą Ewagriańskiego mnicha warunkuje jego ostateczny cel - „poznanie Boga” (Ep. ad Mel. 16; Spirit. sent. 2). Z perspektywy onto-antropologii Ewagriański mnich daje się wobec tego ująć jako typ człowieka ontologalnego $^{25}$ o charakterze teo-ontologalnym ${ }^{26}$. Opisowo rzecz ujmując, jest on typem człowieka nastawionego na bycie sobą, które pozyskuje ostatecznie ze względu na możliwość doświadczenia teo-ontologalnego. Monastyczne, anachoreckie stawanie się sobą w wersji Ewagriańskiej dokonuje się w strukturze samoodniesienia - badającego myśli ${ }^{27}$. Ontologalność Ewagriańskiego mnicha jest wobec tego refleksyjna.

${ }^{20}$ Na temat Ewagriańskiej kategorii hezychii zob. L. Nieścior, Anachoreza w pismach Ewagriusza $z$ Pontu, dz. cyt., zwł. s. 84-98.

${ }^{21}$ Na temat Ewagriańskiej kategorii beznamiętności zob. L. Nieścior, Pojęcie apathei w pismach Ewagriusza z Pontu, „Studia Paradyskie” 6/7 (1996-1997), s. 105-133.

${ }^{22}$ Analiza różnorodnych treści tych pojęć nie wchodzi w zakres badawczy niniejszego artykułu. Ogólnie można przyjąć, że kryją się za nimi zjawiska, które dają się ujmować jako aspekty jednej struktury teo-antropologicznej - doskonałości duchowej Ewagriańskiego człowieka.

${ }^{23}$ Projekt antropologii ontologicznej wypracowujemy zwłaszcza w przygotowywanej rozprawie habilitacyjnej. Elementy tego projektu zostaną niniejszym wprowadzone w maksymalnie wąskim zakresie - stosownie do potrzeb badawczych związanych z podejmowanym problemem. Na temat bycia sobą jako kategorii antropologicznej zob. A. Węgrzecki, Antropologiczny sens bycia sobą, [w:] Wokół filozofii spotkania, Kraków 2014, s. 184-191; A. Węgrzecki, Bycie sobą w świecie współczesnym, [w:] Kondycja człowieka współczesnego, red. Cz. Piecuch, Kraków 2006.

${ }^{24}$ Na temat egzystencji rozumianej jako zadanie zob. W. Luijpen, Fenomenologia egzystencjalna, tłum. B. Chwedeńczuk, Warszawa 1972, s. 325.

25 Przyjmujemy następującą terminologię: „ontologiczny” w odniesieniu do antropologii oznacza rodzaj ujęcia badawczego nakierowanego na badanie człowieka w aspekcie możliwości i powinności bycia sobą; „ontologalność” oznacza wymiar człowieka - bycie (stawanie się) sobą i jego zjawiska.

${ }^{26}$ Termin „teo-ontologalność” stosujemy dla oznaczenia - zjawiska antropologii teologicznej w ujęciu ontologicznym - ludzkiego bycia sobą w relacji do „Boga”; por. przypis poprzedni.

${ }^{27} \mathrm{Na}$ gruncie onto-antropologii badanie myśli ma charakter nie czysto intelektualny, lecz ontologiczny - dotyczy bytowości człowieka. 
Acedia a lype w świetle Ewagriańskiej koncepcji logismoi

Z perspektywy onto-antropologii Ewagriańskie logismoi są formą nieautentyczności ontologalnej w wersji refleksyjnej - formą niezgodności umysłu z samym sobą (por. De octo. spirit. 13) i jako takie stanowią, obrazowo je ujmując, przeszkody w stawaniu się sobą - bardzo ważne dla mnicha. Tę ich ważność Pontyk wyraża słowem „próby”. Poprzez jej sens Ewagriusz wyjaśnia doświadczanie logismoi jako pokus. Ich przezwyciężanie staje się, w ujęciu Pontyka, rodzajem dźwigni ontologalnej, zbliżaniem się do refleksyjnego bycia sobą - poznania samego siebie ${ }^{28}$. Za najtrudniejszą próbę, której przezwyciężenie oznacza największy postęp ontologalny, zostaje przez Ewagriusza uznane doświadczenie acedii (Pr. 28; Ep. 27, 6) jako logismos najbardziej „uciążliwego”29

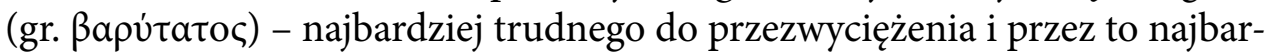
dziej szkodliwego dla egzystencji. Pontyk uzasadnia ten rys acedii przekonaniem, że swym działaniem obejmuje ona całość człowieka, co metaforycznie wyraża słowami: „Jeśli wszystkie inne demony podobne są do wschodzącego i zachodzącego słońca, gdyż obejmują tylko część duszy, to demon południa

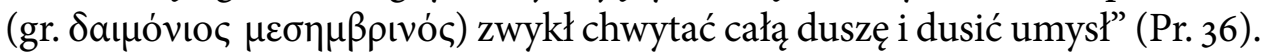

Trudno wykorzystać przywołane powyżej Ewagriańskie uzasadnienie dla wielkości próby acedycznej. Jest ono uwikłane w zaznaczoną powyżej niejednoznaczność co do antropologicznej kwalifikacji acedii. Jednak bez zastrzeżeń można, jak sądzimy, oprzeć się na wartości egzystencjalnej Ewagriańskiego zapisu doświadczenia monastycznego i zakorzenionych w nim sądach Pontyka, w tym mówiących o wielkości acedycznej uciążliwości. Narzędzia potrzebne do uzasadnienia tego rysu acedii powinny wyłonić się w toku poszukiwania antropologicznego wyjaśnienia różnic dzielących acedię i lype. Wstępne spojrzenie na wyłaniające się z pism Ewagriusza egzystencje: lypiczną i acedyczną, zdaje się osłabiać przyjętą wyjściową przesłankę. Zestawienie ich wyglądu rodzi bowiem wrażenie, iż to lype, a nie acedia, wystawia egzystencję na większą próbę. Oto lype wyraża się w stagnacji egzystencji, jej zobojętnieniu i swoistym zamieraniu (De octo. spirit. 11, 12). Przejawem znamiennym acedyka

${ }^{28}$ Wartość ontologalną doświadczenia pokus dobitnie wyraził św. Antoni Egipski: „Nikt nie może wejść do Królestwa Niebieskiego nie wypróbowany. Zabierz pokusy a nikt nie będzie zabawiony”. Św. Antoni, Żywot. Pisma ascetyczne, tłum. E. Dąbrowska i in., Kraków 2005, s. 234.

29 Zob. słowa Ewagriusza: „Demon acedii, nazywany także demonem południa (gr. $\delta \alpha \mu o ́ v i o \varsigma$ $\left.\mu \varepsilon \sigma \eta \mu \beta \rho \imath{ }^{\prime} \varsigma\right)$ jest najuciążliwszy spośród demonów” (Pr. 12). Na temat Ewagriańskiej acedii jako demona południa zob. L. Macheta, Demon południa i zafałszowanie egzystencji. O acedii starożytnego mnicha $i$ „zbędności” inteligenta rosyjskiego XIX wieku, Kraków 2003, passim, zwł. s. 27, 34; L. Misiarczyk, Osiem „logismoi” w pismach Ewagriusza z Pontu, dz. cyt., s. 321-325. 
jest zaś gorączkowa aktywność, wprowadzająca liczne zmiany nakierowane na uskutecznienie dążenia do obranego celu. Jednak wrażenie to osłabia widok konsekwencji acedycznych działań. Zbliżają one mnicha nie do celu ${ }^{30}$, a do porzucenia obranej ścieżki życia ${ }^{31}$.

\section{Acedia a lype w strukturze wzajemnych zależności}

W pismach Ewagriusza można dostrzec, iż cechy acedii i lype odsłaniają się w strukturze ich ścisłej zależności. W świetle słów Pontyka lype jest jednym $\mathrm{z}$ warunków koniecznych ${ }^{32}$ acedii. Ona $\mathrm{z}$ kolei prowadzi, jak postaramy się pokazać, do powstania lype. W ramach takiego właśnie wzajemnego sprzężenia acedii i lype będą wykazywane różnice dzielące je na płaszczyźnie antropologicznej. Podporządkowana temu głównemu celowi analiza obu badanych zjawisk będzie prowadzona w dwóch etapach. Oba te zjawiska: acedia i lype, najpierw zostaną opisane w pojęciach Ewagriańskiej teo-antropologii w ujęciu ontologicznym, a następnie - wyjaśnione z perspektywy aksjologii egzystencjalnej. Celem tych cząstkowych analiz będzie ustalenie źródeł i cech istotnych acedii i lype. Jako pierwsze zostanie rozpatrzone zjawisko lype.

\section{Lype - Ewagriańska teo-antropologia w ujęciu ontologicznym}

W świetle pism Ewagriusza u podstaw lype leży utrata „przedmiotu namiętnego przywiązania” "33, frustracja dążeń do „przedmiotu namiętnego przywiązania” (Pr. 19). W ujęciu Pontyka lype jest „przeszkodą wszelkiego dobra” (De octo. spirit. 11). Ewagriańskie lype ma wymiar, w którym mami pozorem

${ }^{30}$ Por. słowa Ewagriusza: „[...] delikatną roślinę zgiął lekki podmuch, a pomysł odejścia z celi pochwycił ogarniętego przez acedię. [...] Mnich włóczęga jest pustynnym krzakiem, trochę pobył w spokoju i znów go niesie mimo woli. Przesadzona roślina nie przynosi owocu, a włóczący się mnich nie wyda owocu cnoty” (De octo. spirit. 9).

${ }^{31}$ Zob. słowa Ewagriusza: „Przeciw myślom powstającym w duszy na skutek zniechęcenia, które pragną porzucić świętą drogę dobrych uczynków i miejsce zamieszkania” (Antirrh. vi, 52).

${ }^{32}$ Dla potrzeb niniejszych analiz wykorzystujemy pojęcia fenomenologii ontologicznej, pozwalającej badać zjawiska od strony warunków koniecznych (wymiennie: źródeł, podstaw ontologicznych); por. A. Workowski, Ontologiczne podstawy posiadania, Wrocław 2009, zwł. s. 13-15.

33 Por. słowa Ewagriusza: „Niemożliwe jest [...], abyśmy odparli tego wroga [lype - L. M.], gdy jesteśmy namiętnie przywiązani do czegoś na tej ziemi. Tam bowiem zastawia on pułapkę i sprowadza smutek, ku czemu, jak widzi, najbardziej się skłaniamy” (Pr. 19); „Smutek bierze się czasem z niespełnionych pragnień, czasem zaś jest następstwem gniewu" (Pr. 10) - sfrustrowanego (De octo. spirit. 11). 
beznamiętności ${ }^{34}$ (gr. ảđá $\theta \varepsilon ı$ ). Negacja lypiczna kulminuje w „zniszczeniu”35 umysłu. Jego swoiste zamieranie, stagnacja jest konsekwencją lype ${ }^{36}$ (De octo. spirit. 11, 12).

Wyłaniająca się z opisów Ewagriusza wizja lype pozostawia nas z kilkoma ważnymi dla nas kwestiami, wymagającymi rozwinięcia i uściślenia. Jedna z nich dotyczy kluczowego elementu źródeł lype - owego przedmiotu „namiętnego przywiązania” (Pr. 19). Ewagriusz bliżej nie wyjaśnia jego znaczenia. Skupia się tylko na opisie więzi psychologicznej łączącej mnicha z tym przedmiotem (Pr. 10). Podobnie Ewagriusz nie przybliża natury dobra, któremu sprzeciwia się lype. Szeroko opisuje tylko przejawy jego lypicznego zanegowania (De octo. spirit. 11, 12).

\section{Lype - aksjologia egzystencjalna w ujęciu ontologicznym}

W odniesieniu do powyższych opisów Ewagriańskiego lype spróbujemy teraz jego cechy wyjaśnić w pojęciach aksjologii egzystencjalnej. Z jej perspektywy przedmiot „namiętnego przywiązania” (Pr. 19), którego utrata określa źródła lype, daje się ująć jako pewna szczegółowa wartość egzystencji, mylnie brana za konieczną dla jej spełnienia. Lypiczną odpowiedź na utratę tej wartości

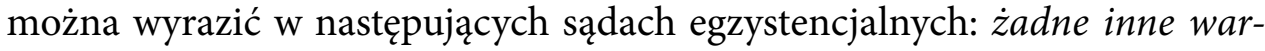
tości pozytywne nie zastąpia tej utraconej, nie wypetnia pustki po niej; więc nie warto urzeczywistniać jakichkolwiek innych wartości - bez tej utraconej $i$ tak nie dadza egzystencji spetnienia. Oparte na tych egzystencjalnych przeświadczeniach lype neguje „wszelkie dobro” (De octo. spirit. 11) w jego sensie nie etycznym, lecz egzystencjalnym. W języku aksjologii egzystencjalnej dobro takie jest nazwą ogólną dla szeregu pozytywnych wartości (naczelnych) szczegółowych, których urzeczywistnienie daje egzystencji spełnienie - pełnię bycia sobą ${ }^{37}$. Ewagriańskie lype polega, w sensie podstawowym, na negowaniu wartości pozytywnych w aspekcie ich urzeczywistnienia (aktualnego i możliwego). Dając egzystencji spełnienie, urzeczywistnienie to staje się

34 Por. słowa Ewagriusza: „Kto się ciągle smuci a pozoruje beznamiętność, podobny jest do chorego, który udaje zdrowego" (De octo. spirit. 12).

35 Por. słowa Ewagriusza: „Symbolem tego demona [lype - L. M.] jest żmija, zwierzę, którego wydzielina dawkowana zgodnie z pożytkiem ludzi, niszczy trucizny innych zwierząt, nieumiarkowanie zaś przyjęta niszczy samą także żywą istotę" (De mal. cogit. 13).

${ }^{36}$ Por. słowa Ewagriusza: „Smutny mnich nie pobudzi swego umysłu do kontemplacji ani nie wzniesienie czystej modlitwy. [...] U barbarzyńców więzień jest skuwany żelazem, a więzień namiętności - smutkiem" (De octo. spirit. 11, 12).

37 Por. W. Stróżewski, Od wartości bytu..., dz. cyt., s. 27. 
sensem i celem jej aksjologicznej aktywności. Prócz aspektu podstawowego w negacji lypicznej da się wyodrębnić, znamiennie refleksyjny, wymiar lype, który ma swój odpowiednik w iluzji aksjologicznej. Egzystencja lypiczna łudzi się w niej przekonaniem, że nie potrzebuje żadnych wartości pozytywnych (urzeczywistnionych), ponieważ osiągnęła już swoje spełnienie. Ostatni istotny wymiar negacji lypicznej i zarazem miejsce jej optymalnego przejawu ma swój egzystencjalny korelat w doświadczeniu samozatraty. W wymiarze tym egzystencja lypiczna podlega niszczeniu ze strony wartości negatywnej w tym jej szczególnym sensie, w którym oznacza ona „nieistnienie wartości pozytywnej”38. Wyrazem doświadczenia lypicznej autodestrukcji jest swoisty ból egzystencji ${ }^{39}$. Konsekwencją lype jest zobojętnienie, stagnacja specyficznie ludzkich władz egzystencji - zanik wszelkiej aktywności aksjologicznej, mającej na celu urzeczywistnienie wartości.

\section{Acedia - Ewagriańska teo-antropologia w ujęciu ontologicznym}

Określmy teraz acedię w pojęciach Ewagriańskiej teo-antropologii w ujęciu ontologicznym. W świetle pism Pontyka acedię warunkuje jedność: lype w jego konsekwencjach ${ }^{40}$ oraz „południa” (Pr. 12). Pierwszy warunek konieczny acedii: konsekwencje negacji lypicznej, został już określony powyżej. Uwaga zostanie skupiona na drugim warunku i jego więzi z lype.

W pismach Ewagriusza południe mnicha jest szczególnym przełomowym momentem dnia. Jest ono przerwą $\mathrm{w}$ trudach monastycznych ${ }^{41}$. W południe mnich aktywnie odpoczywa - podsumowuje trudy przedpołudniowe i zbiera siły, przymierza się do wszczęcia nowych trudów - popołudniowych. Ujęte z perspektywy aksjologii egzystencjalnej Ewagriańskie południe to szczególny

${ }^{8}$ Por. W. Stróżewski, Od wartości bytu..., dz. cyt., s. 28.

39 Zob. słowa Ewagriusza: „Do duszy utrzymującej, z powodu smutku, który ją naszedł, że Pan nie wysłuchuje jej jęków” (Antirrh. IV, 1); „Przeciw myślom, które nie wyczekują pomocy od Boga i smutkiem niszczą duszę" (Antirrh. IV, 4).

${ }^{40}$ Por. słowa Ewagriusza: „Jeśli duch acedii opanuje cię, nie opuszczaj swojej celi i w czasie smutku nie skłaniaj się [ku jego podszeptom]" (Ad mon. 55; zob. też: De mal. cogit. 13); por. Tract. ad Eul. 6, gdzie jako warunek acedii zostaje wskazany, prócz smutku, gniew. Należy przy tym podkreślić, iż w świetle pism Ewagriusza gniew warunkuje acedię: o ile jest sfrustrowany i - w sposób pośredni: poprzez lype; por. słowa Ewagriusza: „Smutek jest przygnębieniem duszy i powstaje z myśli gniewu. Popędliwość jest bowiem pragnieniem zemsty, niedopełnienie zaś zemsty rodzi smutek" (De octo. spirit. 11).

${ }^{41}$ Na temat Ewagriańskiego pojęcia trudów (gr. $\pi$ óvol) monastycznych zob. L. Nieścior, Trudy ( óvoı) jako termin ascetyczny u Ewagriusza z Pontu, „Studia Paradyskie” 5 (1995), s. 81-108. 
moment egzystencji, w którym w bilansie ogarnia ona to, co dokonane, i w zamierzeniach otwiera się na przyszłość. W południe przed egzystencją odsłania się całość jej świata aksjologicznego.

W Ewagriańskie południe doświadczane przez egzystencję lypiczną kulminuje spełniany przez nią akt negacji, natężenie przeżywanego bólu egzystencjalnego. Bólu tego egzystencja może nie wytrzymać. Udręczona „dusza może potajemnie opuścić ciało” (De mal. cogit. 13). Jeśli jednak tego nie uczyni, a egzystencja nie wycofa swej negacji, nie przezwycięży jej afirmacją wartości pozytywnych i tym samym nie umożliwi wszczęcia nowego dążenia do swego spełnienia - wówczas w południe osiągnie apogeum konsekwencja negacji lypicznej - stagnacja władz specyficznie ludzkich. W tym ich totalnym - „południowym” - bezruchu wyraża się jedność warunków koniecznych acedii.

W świetle pism Ewagriusza całkowity bezruch władz specyficznie ludzkich egzystencji wykorzystują jej pozostałe moce: irracjonalne. W południe lypiczne uaktywnią się one w sposób, który Pontyk w ślad za tradycją monastyczną nazwie acedycznym ${ }^{42}$ i sprecyzuje w definicji: „acedia jest jednoczesnym i długotrwałym pobudzeniem przez popędliwość i pożądanie, przy czym ta pierwsza złości się na to, co obecne, drugie zaś pożąda tego, co nieobecne” (In Ps. 118). Przejawami acedii są gorączkowe zmiany, które obejmą całą sferę egzystencji (De octo. spirit. 9). Acedyczna dynamika łudzi pozorem wyjścia egzystencji ze stagnacji lypicznej i podjęcia dążenia do spełnienia, do stanu Ewagriańskiej beznamiętności. O prawdziwym sensie acedycznej aktywności świadczą jej rezultaty. Acedycznie prowadzone trudy ${ }^{43}$ nie przynoszą cnót monastycznych (De octo. spirit. 9), prowadzą do osłabienia władz specyficznie ludzkich ${ }^{44}$, a ostatecznie - do porzucenia ascezy mniszej (Antirrh. vi, 52). Pisma Ewagriusza powalają sądzić, iż acedia nie wyłania się jako nowy moment w rozwoju lype. Jej zaistnienie oznacza jakościową przemianę egzystencji. W przemianie tej dochodzi do aktywizacji nowej funkcji mocy irracjonalnych

${ }^{42}$ Por. słowa Ewagriusza: „Demon acedii, nazywany także demonem południa [...]. Nachodzi mnicha koło godziny czwartej i osacza jego duszę aż do godziny ósmej” (Pr. 12). Pisma Ewagriusza pozwalają sądzić, że myśli acedii uaktywniają się w południe konkretne - związane z określoną porą dnia - wyłącznie w egzystencji starożytnego mnicha jako miejscu źródłowego ich występowania. Więcej zob. L. Macheta, Demon południa i zafałszowanie egzystencji..., dz. cyt., s. 34-35.

${ }_{43}$ Por. słowa Ewagriusza: „Przeciw myśli zniechęcenia, odrywającej nas od czytania i od nauki słów natchnionych oraz mówiącej, że pewien święty starzec tylko dwanaście psalmów śpiewał i podobał się Bogu” (Antirrh. 213).

${ }^{44} \mathrm{O}$ acedii jako „osłabieniu duszy” zob. De octo. spirit. 13. 
egzystencji i wobec tego - do pojawienia się nowego, różnego od lypicznego, stosunku do wartości.

\section{Acedia - aksjologia egzystencjalna w ujęciu ontologicznym}

Wyłaniająca się z opisów Ewagriusza wizja acedii pozostawia nas z niejasnością co do podstaw kresu acedycznej aktywności - jej bezpłodności. By je określić, musimy bliższej przyjrzeć się przedmiotowi dwojakiego ruchu acedii. Spróbujemy teraz odsłonięte powyżej jej cechy wyjaśnić w pojęciach aksjologii egzystencjalnej. Skupimy się przy tym na znamiennie refleksyjnym wymiarze acedii, w którym pozoruje ona dążenie do cnót monastycznych ${ }^{45}$.

Przyjrzyjmy się bliżej acedycznemu ujęciu wartości. Acedia sprawia wrażenie ruchu podejmującego wszystkie wartości potrzebne do urzeczywistnienia wartości naczelnych egzystencji. Wartości umożliwiające urzeczywistnienie innych wartości to wartości podstawowe ${ }^{46}$. W przypadku typu człowieka uosabianego przez Ewagriańskiego mnicha wartości podstawowe muszą być - odpowiednio do jego wartości naczelnych - wysokie ${ }^{47}$ i jako takie nasycone jakością trudu ${ }^{48}$. Do ich podjęcia nie są zdolne moce irracjonalne. Właściwym obiektem pożądliwości i popędliwości jako takich są bowiem

${ }^{45}$ Więcej na temat Ewagriańskiej acedii ujmowanej jako zafałszowanie egzystencji zob. L. Macheta, Demon południa i zafatszowanie egzystencji..., dz. cyt., zwł. Rozdział II: Acedia jako fatszywy ruch duchowy.

${ }^{46}$ Pojęcie „wartości podstawowych” stosujemy w znaczeniu określonym przez W. Stróżewskiego: „Te wartości, których spełnienie warunkuje w sposób konieczny samą możliwość realizacji wartości innych, proponuję nazwać wartościami podstawowymi”, zob. W. Stróżewski, Istnienie i wartość, Kraków 1981, s. 110.

47 Rozróżnienie na wartości wysokie i niskie przyjmujemy w sensie Schelerowskim, zob. M. Scheler, Wartości „wyższe” i „niższe”, [w:] Z fenomenologii wartości, tłum. W. Galewicz, Kraków 1988, s. 67-84.

${ }^{8} \mathrm{O}$ związanym z jakością trudu oporze towarzyszącym realizacji wartości, zwł. wysokiej, zob. J. Tischner, Świat ludzkiej nadziei. Wybór szkiców filozoficznych 1966-1975, Kraków 1992, s. 178. Charakter, nastawionej na wartości wzniosłe, egzystencji mnicha odsłania się w słowach Ewagriusza skierowanych do adepta życia monastycznego: „Ponieważ dostrzegłem w tobie chęć wyruszenia ku życiu i wydało ci się słusznym wstąpić na drogę, o której Panu poucza, że jest wąska, pełna trudów i uciążliwości, postanowiłem udzielić ci rady, skoro zapytałeś mnie, w jaki sposób masz zacząć praktykę [ascetyczną] i jak masz założyć fundament pod nawrócenia” (Protr.). Por. także słowa z Pierwszej Księgi Starców: „Jeden z ojców zapytał abba Jana Karła, co to jest mnich. A on odpowiedział: «Trud. Bo we wszystkim zadaje sobie trud w każdej sprawie: oto czym jest mnich»", zob. Pierwsza Księga Starców. Gerontikon, tłum. M. Borkowska, Kraków 1992, s. 128. 
wartości niskie (tzw. wartości hedonistyczne ${ }^{49}$ i witalne). Pożądliwość jako taka odnosi się do wartości (niskich) pozytywnych przyszłych ${ }^{50}$, zaś popędliwość jako taka - do wartości (niskich) negatywnych obecnych ${ }^{51}$. Acedycznie pobudzone moce irracjonalne przejmują w egzystencji kompetencje władz specyficznie ludzkich w zakresie stosunku do wartości podstawowych. Acedyk odczuwa te wartości tylko poprzez moce irracjonalne $e^{52}$. Dla nich wartości podstawowe wysokie są niewidoczne. Wobec nich acedyk wykazuje bez-troskę.

Przyjrzyjmy się teraz acedycznemu odniesieniu do wartości w świetle rozróżnienia na wartość celu, wyznaczonego przez wartości naczelne egzystencji, i wartości dóbr ${ }^{53}$ jako środków do niego, wyznaczonych przez wartości podstawowe egzystencji. Środki jako takie pozostają względem celu w stosunku odpowiedniości. Cel Ewagriańskiej egzystencji jest wzniosły - trudny do osiągnięcia $^{54}$. Środki skuteczne, odpowiednie do osiągnięcia takiego celu, stanowią jedynie przedmioty nasycone wartością trudu. Acedia wypacza zasadę wyboru środków do celu. W acedii wybór tych środków nie kieruje się obiektywną wagą

49 Wymiennie: tzw. wartości wygody.

50 Por. św. Tomasz z Akwinu, Suma teologiczna. Uczucia, t. 10, tłum. J. Bardan, London 1967, S. 86 .

${ }^{51}$ Św. Tomasz z Akwinu, Suma teologiczna..., dz. cyt., s. 241.

${ }^{52}$ Na potrzeby wyjaśnienia acedycznego ujęcia wartości przyjmujemy, w odniesieniu do antropologii Maxa Schelera, iż w człowieku da się wyróżnić cztery warstwy: sferę zmysłową (ciało fizyczne), witalną (ciało jako jedność), sferę psychiczną i duchową (osoba). Na temat antropologii Schelera zob. P. Orlik, Fenomenologia świadomości aksjologicznej. (Max Scheler - Dietrich von Hildebrand), Poznań 1995, s. 64; M. M. Baranowska, Bóg w myśli Schelera, Kraków 2011, zwł. Rozdział II: Osoba $i$ wartość. Acedyczne czucie (termin Schelerowski) wartości jest spełniane poprzez sferę zmysłową i witalną. Zachodząc w najniższych warstwach egzystencji, acedyczne ujmowanie wartości przejawia się w afektywnych gorączkowych pobudzeniach, w tym o charakterze hipochondrycznym; por. słowa Ewagriusza: „Przeciw myśli zniechęcenia, nakłaniającej do szukania innej celi pod pretekstem, że mieszkanie, $\mathrm{w}$ jakim uprzednio się przebywało, jest obrzydliwe i pełne wilgoci, $\mathrm{z}$ której biorą się wszystkie choroby" (Antirrh. 26; zob. także: Antirrh. vi, 32, 36).

53 Termin używany w sensie Schelerowskim: „[...] dobro jest rzecza ukonstytuowana przez wartość (ein Wertding) [...] Dopiero w dobrach wartości stają się «rzeczywiste»”, zob. M. Scheler, Dobra a wartości, [w:] Z fenomenologii wartości..., dz. cyt., s. 54.

${ }^{54}$ Zauważmy przy okazji, że acedia w sposób źródłowy pojawia się w egzystencji nakierowanej na ideały, na cele wyznaczone przez wartości wysokie i tym samym nasyconej trudem; jednym z wzorcowych ujęć takiej egzystencji jest Ewagriańska wizja mnicha. W egzystencji nastawionej wyłącznie na cele niskie, łatwe i osiągalne przy pomocy środków wygodnych i sprzyjających zdrowiu - acedia nie występuje w czystej postaci. 
ich wartości, lecz tym, co zaspakaja pożądliwość i popędliwośśc5. Acedyczna pożądliwość sięga po przedmioty, którym mylnie nadaje wartość skuteczności odpowiedniości dla celu wzniosłego - a które w rzeczywistości są nasycone jedynie wartością wygody i służącą witalności. Dlatego acedyk nie osiąga tego, czego acedycznie pożąda. Wartość (skuteczności), po którą sięga, jest bowiem fałszywa. Acedyczna popędliwość odrzuca zaś przedmioty, którym mylnie nadaje wartość nieskuteczności w osiąganiu celu wzniosłego, a które w rzeczywistości są nasycone jedynie wartością niewygody i sprzeciwiającą się witalności. Dlatego acedyk nie usuwa tego, czemu acedycznie się sprzeciwia. Wartość (nieskuteczności), którą odrzuca, jest bowiem fałszywa. Acedyczny ruch mocy irracjonalnych, parodiując rzetelne odniesienie do wartości podstawowych egzystencji, staje sięźródłem frustracji. I jako taki dostarcza podstaw do powstania lype. Warunkowana nim acedia okazuje się samonapędzającą się strukturą zła.

\section{Podsumowanie}

Przeprowadzone analizy pozwalają sądzić, że badane dwa Ewagriańskie zjawiska: acedia i lype - wyjaśniane z perspektywy aksjologii egzystencjalnej - dzieli różnica jakościowa. Oba zjawiska wskazują bowiem na różne wymiary w egzystencji, oba są wyznaczone przez nastawienie na różne typy wartości. Lype określa wymiar pełni (bycia sobą) egzystencji, zaś ruch acedyczny - jej podstawy. Obiektem negacji lypicznej i zarazem przedmiotowym aksjologicznym odpowiednikiem spełnienia egzystencji są jej wartości naczelne pozytywne $\mathrm{w}$ aspekcie ich urzeczywistnienia; zaś przedmiotem aksjologicznym acedii są wartości podstawowe egzystencji.

Na zakończenie spróbujmy, pozyskanymi w toku analiz pojęciami, wyjaśnić, dlaczego acedia jest bardziej niż lype uciążliwa - trudniejsza od niego do przezwyciężenia.

Lype okazuje się swoistą autonegacją władz specyficznie ludzkich w sferze pełni egzystencji, wiodącą w konsekwencji do bezruchu w całym jej obszarze, w tym - jej podstaw. Działające lypicznie specyficznie ludzkie władze egzystencji same mogą wycofać swoją autonegację. Aktem afirmacji wartości pozytywnych mogą odblokować świat wartości i tym samym znieść stagnację

55 Por. słowa Ewagriusza: „Przeciw myśli [pochodzącej od] demona zniechęcenia, nienawidzącej pracy fizycznej, którą zna, chcącej natomiast uczyć się innej pracy, efektywniejszej i łatwiejszej” (Antirrh. VI, 1). 
egzystencji. Acedia blokuje samą możliwość podjęcia dążenia do spełnienia egzystencji. Acedycznie uaktywnione, imitujące urzeczywistnianie wartości podstawowych, moce irracjonalne skutecznie powstrzymują ruch specyficznie ludzkich władz w sferze podstaw egzystencji. Acedyczny ruch mocy irracjonalnych prowadzi w swej konsekwencji do osłabienia władz specyficznie ludzkich. Wraz z tym osłabieniem acedycznie nastawione moce irracjonalne rosną w siłę. Dlatego z perspektywy przebiegu egzystencji jej, stopniowo osłabianym, władzom specyficznie ludzkim coraz trudniej samym zapanować nad acedycznie nakierowanymi mocami irracjonalnymi, coraz trudniej podjąć starania o urzeczywistnienie rzetelnych wartości podstawowych. Specyficznie acedycznym znamieniem wypaczenia tych mocy staje się przewlekłość. W przebiegu egzystencji jest ona doświadczana jako uciążliwość. Z tej właśnie perspektywy ujawnia się oparta na przewlekłości acedyczna szkodliwość. Wyraża się ona w stopniowym niszczeniu w egzystencji zdolności do rzetelnego podejmowania wartości (podstawowych) - dążenia do jej spełnienia. Trudność w przezwyciężeniu acedii dodatkowo wzmacnia ograniczenie możliwości w skorzystaniu z pomocy innych ludzi. Jej przyjęcie wymaga bowiem od acedyka sprostania wymogom posłuszeństwa (Antirrh. vi, 2, 50, 55) - jednej Z wartości podstawowych. Im acedia źródłowo się sprzeciwia.

Zjawisko uciążliwości acedycznej pojawia się w pismach Ewagriusza nie tylko w - tematycznie nas interesującym - odniesieniu do lype, lecz także w relacji do wszystkich logismoi. Ewagriański zapis podkreśla, że acedia stanowi ich złowrogie, poprzedzone lype (De octo. spirit. 11, 12), zwieńczenie (Pr. 12). W acedii kulminuje antyludzki rys zła egzystencjalnie znaczącego, wymierzony przeciwko możliwości i powinności bycia sobą. Acedyczna przewlekłość degraduje specyficznie ludzkie oblicze egzystencji. Przesłania je spazmatycznością swego dwojakiego pobudzenia irracjonalnego. Nadaje ona acedykowi wygląd zgoła odmienny od znamionującego lypika - wprawdzie zmartwiałego, jednakże, uszlachetnionego specyficznie ludzkim bólem egzystencji. Akcentowany w naszych analizach format opresji acedycznej nie powinien jednak przesłaniać związanej z nią przez Ewagriusza nadziei - na wielką egzystencjalną wygraną. Stawką $\mathrm{w}$ zmaganiach $\mathrm{z}$ acedią, powróćmy do początkowych uwag, jest wypróbowana wytrwałość, którą Ewagriusz nazwie: „pancerzem wyciszenia” (gr. நंбuxía) (De vitiis. 4), „potwierdzeniem cnót” (De vitiis. 4). Nadto w Rozdziale dwunastym słynnego Practikus o zwycięstwie w walce $z$ acedią napisze: „Żaden inny demon nie podąża za demonem acedii. Tak więc po wygranej walce ogarnia duszę uspokojenie (gr. ந̇бvxía) i niewysłowiona radość" (Pr. 12). 


\section{Abstrakt}

W artykule bada się problem relacji dwóch zjawisk Ewagriańskiej teo-antropologii: acedii (zniechęcenie) i lype (smutek). Problem jest rozpatrywany z perspektywy antropologii ontologicznej (bada człowieka od strony możliwości i powinności bycia sobą). Celem analiz jest wykazanie i wyjaśnienie różnic dzielących acedię i lype poprzez ich uzasadnienie antropologiczne. Cel jest osiągany przy pomocy pojęć aksjologii egzystencjalnej. W artykule zmierza się do pokazania, że acedia i lype wskazują w człowieku na różne wymiary: acedia wypacza w egzystencji sferę nastawienia na wartości podstawowe; lype wypacza w egzystencji obszar nastawienia na wartości pozytywne, których urzeczywistnienie oznacza jej spełnienie.

\section{SŁOWA KLUCzowe}

acedia, lype, teo-antropologia ontologiczna, aksjologia egzystencjalna, bycie sobą

\section{Abstract}

\section{Acedia and lype in the writings of Evagrius}

\section{Ponticus. Ontological theo-anthropology}

The article examines the problem of the relationship between the two phenomena of the Evagrian theo-anthropology: acedia (listlessness) and lype (sadness). The problem is considered from the perspective of ontological anthropology (a human being is being studied from the side of possibilities and obligations of being oneself). The purpose of the analysis is to demonstrate and explain the differences between acedia and lype in terms of their anthropological justification. This goal is attained through the concepts of existential axiology. The article seeks to demonstrate that acedia and lype point in the human being to two different dimensions: acedia distorts in the existence the sphere of the attitude towards basic values; lype distorts in the existence the sphere of attitudes towards positive values, the realization of which signifies a fulfillment of existence.

\section{KEY WORDS}

acedia, lype, ontological theo-anthropology, existential axiology, being oneself

\section{BibLIOGRAFIA}

Św. Antoni, Żywot. Pisma ascetyczne, tłum. E. Dąbrowska i in., Kraków 2005. Ewagriusz z Pontu, Pisma ascetyczne, t. 1, tłum. K. Bielawski i in., Kraków 1998. 
Ewagriusz z Pontu, Pisma ascetyczne, t. 2, tłum. M. Grzelak i in., Kraków 2005.

Evagrius of Pontus, The Greek Ascetic Corpus, ed. and trans. R. E. Sinkiewicz, New York-Oxford 2003.

Baranowska M. M., Bóg w myśli Schelera, Kraków 2011.

Kaznowski P., Krótka historia metafizycznego znużenia, „Christianitas” 44 (2010), s. $40-57$.

Leloup J.-Y., Hezychazm. Zapomniana tradycja modlitewna, tłum. H. Sobieraj, Kraków 1996.

Luijpen W., Fenomenologia egzystencjalna, tłum. B. Chwedeńczuk, Warszawa 1972. Macheta L., Aktualność Ewagriańskiej koncepcji ośmiu logismoi. Antropologia duchowości, [w:] Chrześcijaństwo a wspótczesne koncepcje człowieka, red. L. Suchanek, Kraków 2013, s. 131-141.

Macheta L., Demon południa i zafałszowanie egzystencji. O acedii starożytnego mnicha $i$ „zbędności” inteligenta rosyjskiego XIX wieku, Kraków 2003.

Misiarczyk L., Osiem „logismoi” w pismach Ewagriusza z Pontu, Kraków 2007.

Nault J.-Ch., Acedia: Enemy of spiritual joy, „Communio” 31 (2004), s. 236-258.

Nieścior L., Anachoreza w pismach Ewagriusza z Pontu, Kraków 1997.

Nieścior L., Kategorie myśli w nauce ascetycznej Ewagriusza $z$ Pontu, „Roczniki Humanistyczne" 44 (1996) z. 3, s. 203-230.

Nieścior L., Pojęcie apathei w pismach Ewagriusza $z$ Pontu, „Studia Paradyskie” 6/7 (1996-1997), s. 105-133.

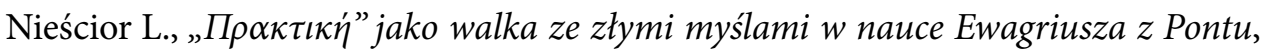
„Vox Populi” 17 (1997) t. 32-33, s. 105-113.

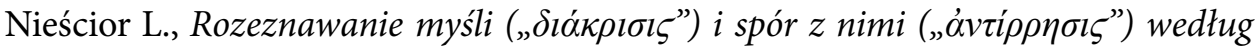
Ewagriusza z Pontu, [w:] Droga doskonalenia chrześcijańskiego w epoce patrystycznej, red. F. Drączkowski, J. Pałucki, Lublin 1997, s. 31-56.

Nieścior L., Smutek w nauce Ewagriusza z Pontu, „Życie Duchowe” 59 (2009), s. 24-34. Nieścior L., Trudy (זóvoı) jako termin ascetyczny u Ewagriusza $z$ Pontu, „Studia Paradyskie" 5 (1995), s. 81-108.

Orlik P., Fenomenologia świadomości aksjologicznej. (Max Scheler - Dietrich von Hildebrand), Poznań 1995.

Pierwsza Ksiega Starców. Gerontikon, tłum. M. Borkowska, Kraków 1992.

Przybylski R., Uraz do materii. Esej o nadmiarze możliwości, „Znak” (1993) nr 458(7), s. $87-110$.

Scheler M., Dobra a wartości, [w:] Z fenomenologii wartości, tłum. W. Galewicz, Kraków 1988, s. 46-59.

Scheler M., Wartości „wyższe” i „niższe”, [w:] Z fenomenologii wartości, tłum. W. Galewicz, Kraków 1988, s. 67-84. 
Stróżewski W., Istnienie i wartość, Kraków 1981.

Stróżewski W., Od wartości bytu do bytu wartości, [w:] Dziedzictwo aksjologii fenomenologicznej. Studia i szkice, red. P. Duchliński, Kraków 2011, s. 15-33.

Tischner J., Świat ludzkiej nadziei. Wybór szkiców filozoficznych 1966-1975, Kraków 1992.

Św. Tomasz z Akwinu, Suma teologiczna. Uczucia, t. 10, tłum. J. Bardan, London 1967. Węgrzecki A., Antropologiczny sens bycia sobą, [w:] Wokół filozofi spotkania, Kraków 2014, s. 184-191.

Węgrzecki A., Bycie soba w świecie współczesnym, [w:] Kondycja człowieka współczesnego, red. Cz. Piecuch, Kraków 2006, s. 15-32.

Workowski A., Ontologiczne podstawy posiadania, Wrocław 2009. 